\title{
The Analysis on Comprehensive Production Capacity about Jilin Food Crops
}

\author{
Zhang Guofeng \\ Depadment of Chinese Medicine,Jilin Agricultural science and Tochnology college,jilin, \\ jilin Province,132101,china \\ 578174945@qq.com
}

Keywords: Grain industry; Jilin city; Planting area

\begin{abstract}
Grain industry is a mainstay industry of Jilin, and an important part of Jilin economic development. Taking Jilin area as the research object, and on the basis of Jilin statistical yearbook from 2005 to 2014, this paper analyses Jilin overall grain production capacity from the agricultural output value, food crops planting area and production etc which attempts to provide advice that can improve Jilin agricultural sustainable development.
\end{abstract}

Jilin located in the middle east with fertile valley and natural resources, is the important commodity grain base of the country.For many years,our city gives play to the resource advantage,strengthens introducing innovation with increasing the farmers' income and make important contribution to grain industry in the whole nation regardless of our province.

\section{The Analysis of Changes in Agricultural Output Value}

The Analysis about Changes in Total Output Value of Farming, Forestry, Animal Husbandry, Side-line Production and Fishery. Based on figure 1, total output value of farming, forestry, animal husbandry, side-line production and fishery tended to increase fluctently since 2005.To2014, total output value reached an all-time high from157.3billion to475.1 billion. Comparedwith2005, itincreased by $200.2 \%$.As a whole,farming,forestry,animal husbandry, side-line production and fishery had various developments and occupied an important position in Jilin economic system which played a key role in peasants increase income, industry synergism and economic development.

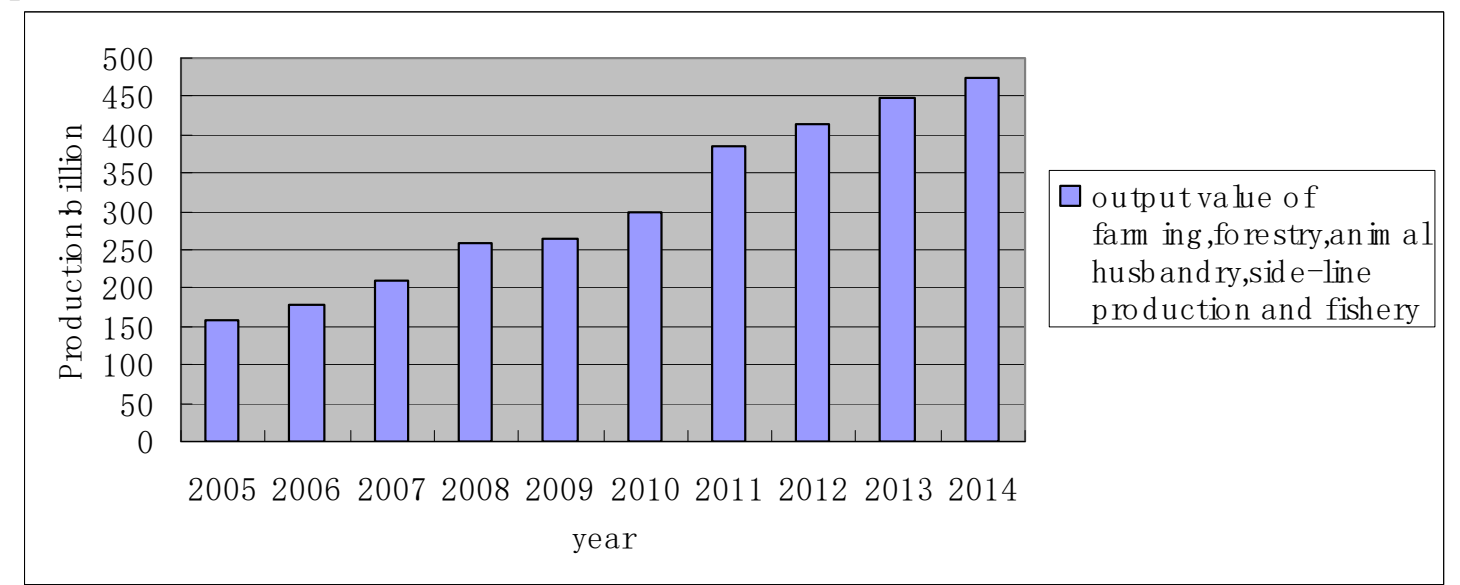

Figure 1 Total output value of farming, forestry, animal husbandry, side-line production and fishery in Jilin from 2005 to 2014

Under the reform and opening policy and the correct leadership of the provincial government ,Jilin province has increased the investment in three agriculture, and stregthened the construction of farmland irragation system ,agricultural comprehensive development and rural infrastructure construction.It carry out well farmers' subsidy system and increase grain price,so grain internal 
structure changes;high-yield grain crops rise constantly and the price of corn and rice sustain rising.Because of the effect of income ,main crops production such as corn increase gradually which improve peasant production enthusiasm.Secondly,with industrial Structure adjustment, total output of the pig cattle and sheep and so on stably increases and healthy fishery cultivation constantly strengthens.Under conversion of cropland to forest,protection and utilization of forest resources is carried out well which leads to increasing primary industry stably. As a whole, The proportion in output value of agriculture increase gradually which shows agriculture is a mainstay industry of Jilin and conform to agricultural modernization in Jilin.

The Analysis About Changes in Agricultural Output Value. Based on table 1, agricultural output value showed an increasing tendency from 2005 to 2013,but it decreased in 2014. The proportion of agricultural production in farming, forestry, animal, husbandry, side-line production and fishery decreased from 2005 to 2009.It showed an increasing tendency from 2009 to 2013, but it decreased in 2014. On the one hand, according to output value and structure proportion, structure system of farming, forestry, animal husbandry, side-line production and fishery changed because of Jilin's economic restructuring .Jilin province carried out a policy that conversion of part of hillside farm to forest leaded to decrease of planting area and caused decrease of agricultural output value in 2014.

Table 1 agricultural output value in Jilin from 2005 to 2014

\begin{tabular}{|c|c|c|c|c|c|c|c|c|c|c|}
\hline Year & 2005 & 2006 & 2007 & 2008 & 2009 & 2010 & 2011 & 2012 & 2013 & 2014 \\
\hline $\begin{array}{l}\text { Agricultural output } \\
\text { value/hundred million }\end{array}$ & 75.6 & 85.7 & 100 & $\begin{array}{l}117 . \\
1\end{array}$ & $\begin{array}{l}119 . \\
9\end{array}$ & $\begin{array}{l}137 . \\
6\end{array}$ & $\begin{array}{l}181 . \\
5\end{array}$ & $\begin{array}{l}212 . \\
4\end{array}$ & $\begin{array}{l}238 \\
2\end{array}$ & $\begin{array}{l}197 . \\
1\end{array}$ \\
\hline $\begin{array}{l}\text { The proportion in } \\
\text { output value of } \\
\text { farming,forestry,animal } \\
\text { husbandry,side-line } \\
\text { production and fishery }\end{array}$ & 48.1 & 48.2 & - & 45.5 & 45.4 & 45.8 & 47.1 & 51.4 & 53.1 & 41.4 \\
\hline
\end{tabular}

\section{The Analysis of Food Crops Planting Area}

Based on table 2 food crops planting area, it showed an increasing tendency from 2009 to 2013, but decreased in 2014. Equal to 2012, it was lower than that in 2013 and equated changes in agricultural output value which proved implementation about conversion of part of hillside farm to forest to be effective. On the one hand,advanced technology in Jilin is demonstrated and extended.For example soil amelioration techniques and fertilization technique are carried out which recover impoverished soil and use efficiency of land is increased.So farmland is protected and used.Because of the effect of market demand,it is necessary to adjust crop planting structure from increasing the harvest of the crops and enhancing crop quality.

Table 2 Food crops planting area in Jilin from 2009 to 2014 (unit: million ha)

\begin{tabular}{ccccccc}
\hline Year & 2009 & 2010 & 2011 & 2012 & 2013 & 2014 \\
\hline Planting area & 59.8 & 61.3 & 61.9 & 64.5 & 65.2 & 64.5 \\
\hline
\end{tabular}

Based on table 3main food crops planting area, Corn planting area showed an increasing tendency year by year .It slightly decreased in 2014,but not satisfactorily. Rice planting area is basically stable. Soybean planting area showed an decreasing tendency. Compared with 2009, it decreased by over 50\% in 2014.Soybean planting area decreased because imported soybeans impacted domestic market which lead to Soybean price reducing and cost of planting increasing. So rate of return was lower than corn and rice. Farmers changed soybean planting area to plant other economic crops from the perspective of income. 
Table 3 Main food crops planting area in Jilin from 2009 to 2014 (unit: million ha)

\begin{tabular}{ccccccc}
\hline Year & 2009 & 2010 & 2011 & 2012 & 2013 & 2014 \\
\hline Corn & 38.1 & 39.8 & 43.1 & 45.1 & 47.1 & 46.9 \\
Rice & - & - & - & 13.8 & 13.5 & 13.6 \\
Soybean & 6.8 & 6.7 & 5.3 & 4.3 & 3.6 & 3.1 \\
\hline
\end{tabular}

\section{The analysis about changes in food crops production}

Based on table 4,corn production changed little from 2009 to 2011,but it significantly grew in 2012and 2013.Compared with the corresponding period, it slightly decreased in 2014.Rice production showed an stable increasing tendency.Compared with 2009 , it increased by over $10 \%$ in 2014. Soybean production increased from 2009 to 2010,but after that it decreased year by year.Until 2014 Soybean production account for $41 \%$ of 2010 .This is because rural planting Structure was adjusted, which lead ed to decrease of planted area and production.

Table 4 Changes in main food crops production in Jinlin

\begin{tabular}{ccccccc}
\hline Year & 2009 & 2010 & 2011 & 2012 & 2013 & 2014 \\
\hline $\begin{array}{c}\text { Corn/ten thousand } \\
\text { tons }\end{array}$ & 247.8 & 248.7 & 247 & 266.3 & 305.3 & 300 \\
$\begin{array}{c}\text { Rice/ten thousand } \\
\text { tons } \\
\begin{array}{c}\text { Soybean/ten } \\
\text { thousand tons }\end{array}\end{array}$ & 90.5 & 93.02 & - & - & 97.4 & 99.7 \\
\hline
\end{tabular}

Based on figure 2, Jilin's main crop tends to corn, accounting for $72.5 \%$ in 2014 .Next corp was rice and reached $24.1 \%$. The both crop account for $96.6 \%$ of all crop production. Combined with table 4, Corn and rice had dominant position, and it would not changed in a short term.But the proportion would have some changes that dominant position of rice would appear gradually. Corn and rice are still main crops in Jilin. The price of them rise constantly.Farmers plant high profit crops from the perspective of increasing the harvest of the crops . With adjusting crop planting structure,the proportion of corn and rice will have some changes, but it will not changed in a short term.

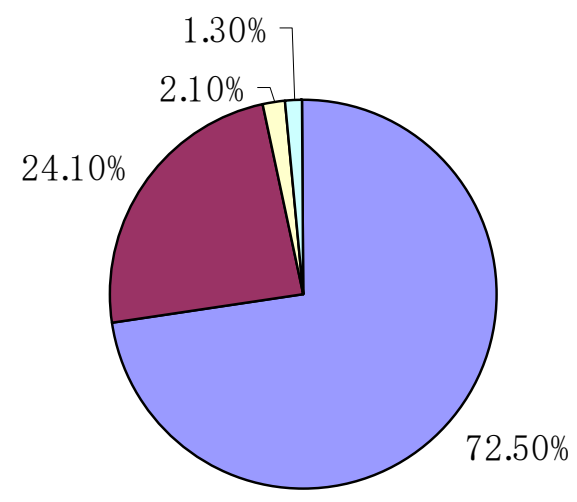

Com/ten thousand tons

$\mathrm{R}$ ice/ten thousand tons

$\square$ Soybean/ten thousand tons $\square$ else

Figure 2 The proportion of main crop in grain total yield in Jilin (\%) 


\section{Conclusion}

Grain industry is still mainstay industry of Jilin.Planting structure influenced by conversion of cropland to forest,market and scientific technology had fluctuating changes.But according to whole development trend,dominant position of main crop would not change.Corn,rice and Soybean are still main crops.

\section{References}

[1]Chang chunshui,The Analysis on Food Crops Production in Jilin,[J].Agriculture of Jilin,2014.09. [2]He xiuli,St u d y on Pattern Changes and Influencing Factor of Grain Production in Jilin Province.[J].Journal of Anhui Agricultural Sciences,2007.05.

[3] Gu lili,The Analysis on Comprehensive Production Capacity about Jilin Food Crops,[J].Changbai Journal,2008.06.

[4]Yin chengjie, Thinking about Improving Crop Comprehensive Production Capacity, [J]. Problem of Agricultural Economy,2005.01.

[5]Jie zongfang,Strategic Way to Increase Comprehensive Gain Production Ability in Henan

Province, ,[J].Research of Agricultural Modernization,2011.07.

[6]Zhang xuelang,Crop Comprehensive Production Capacity and national food security,[J].Journal of Social Science of Hunan Normal University,2011.11. 